\title{
Responding to Change - Criteria and Indicators for Managing the Transformation of Vegetated Landscapes to Maintain or Restore Ecosystem Diversity
}

\author{
Graham A. Yapp and Richard Thackway \\ Additional information is available at the end of the chapter
}

http://dx.doi.org/10.5772/58960

\section{Introduction}

Australia is an old, flat and dry continent that has thin and nutrient poor soils. However, as an island continent with a long separation from other land masses, it has distinctive and highly endemic terrestrial biota - for example, about $92 \%$ of flowering plants, $85 \%$ of terrestrial mammals and $89 \%$ of reptiles [1, 2].

European settlement, beginning only towards the end of the 18th century, brought the introduction of pastoralism and cropping to landscapes where the previous human impact had mainly been the use of fire to assist hunting [3]. Various studies with a focus on the loss of species suggest that, since European settlement in the late 18th Century, Australia has had the world's highest rate of extinctions of mammalian fauna and parallel losses of biodiversity across many of its ecosystems $[4,5]$.

Concern about the loss of biodiversity is not new and not surprising. The major causes are outlined below, but the context, in almost all cases, has been land use change, inappropriate management of fire regimes, and/or ineffective management of threats imposed by introduced, often highly invasive, plants and animals. Also, historically there was a general unwillingness to learn about the structure, composition and function of Australia's ecosystems and to adapt land management practices that had been learned in Europe and imported to Australian ecosystems.

Biodiversity is fundamentally important to ecosystem function [6, 7]. At local scales, biodiversity dependent ecosystem processes provide key ecosystem services - e.g. pollination, the generation of soils and the recycling of nutrients. At wider landscape or regional scales the role of biodiversity in ecosystem function and the provision of ecosystem services such as 
regulation of the hydrological regime and control of soil erosion may be less direct but nevertheless important $[8,9]$.

With growing concern about the impacts of global warming, the capacity of managers to anticipate, recognise and respond to climatic variability will be a key requirement for maintenance of ecosystem function and ecosystem services that depend on biodiversity.

Vegetation is commonly used as the key descriptor of Australian landscapes and the condition of native vegetation is widely used as an indicator of value for biodiversity and the potential for its protection and maintenance. We describe an approach (VAST) by which the condition of vegetation can be effectively described in terms of three diagnostic components - its structure, composition and regenerative capacity [10]. VAST provides a rationale and method for measurement, monitoring and mapping change in 22 indicators of ecosystem structure, composition and function (i.e. key ecological characteristics) over time. Case studies show that purposeful redirection of the way land is managed is supporting the recovery of biodiversity through the transformation of vegetation condition.

\section{Land use in Australia}

Almost $64 \%$ of Australia's land is being used to meet the food and fibre and domestic needs and to provide export income to support a population that has grown, by current estimates, to exceed 23.5 million [11, 12]. Of the total land area, only a small proportion - less than $4 \%$ - is under intensive agricultural and urban use where native vegetation has, in general, been completely removed. About $2 \%$ is used for production forestry including plantations. Around $57 \%$ of the land area has been modified for agriculture and for pastoral use, with the bulk of this area used for livestock grazing on natural or modified pastures [see Table 1]. In areas that have been cleared for agriculture (primarily cereal cropping) and for grazing on improved pastures, remnant areas of native vegetation provide a much-reduced but very important reservoir for biodiversity. However, grazing has had considerable impact on biodiversity even where it uses natural vegetation in semi-arid and arid landscapes.

On the other side of the ledger, nearly $37 \%$ of Australia's land is in national parks, nature reserves and other protected areas (see Table 1). These areas contribute to maintenance of biodiversity as the major component of Australia's National Reserve System (see below). Extensive areas where use is limited or negligible also contribute to biodiversity conservation objectives although, despite being little affected by (or in advanced recovery from) clearing, the impact of fire and feral animals can be significant in these areas.

Changes in land use and land management in Australia are tracked and mapped by cooperative national programs $[1,2,15,16]$. Related arrangements are also in place for describing and mapping change in vegetative cover [17]. 


\begin{tabular}{|c|c|c|}
\hline LAND USE & $\begin{array}{c}\text { AREA } \\
\text { (sq. km) }\end{array}$ & $\begin{array}{c}\text { Proportion } \\
\text { (\%) }\end{array}$ \\
\hline Dryland cropping and horticulture & 256616 & 3.33 \\
\hline Irrigated cropping and horticulture and intensive animal and plant production & 20146 & 0.21 \\
\hline Grazing modified and irrigated pastures & 730193 & 10.50 \\
\hline Grazing native vegetation & 3558785 & 46.30 \\
\hline Production and plantation forestry & 138243 & 1.80 \\
\hline Nature conservation & 569240 & 7.41 \\
\hline Other protected areas, including Indigenous uses & 1015359 & 13.21 \\
\hline Areas of minimal use & 1242715 & 16.17 \\
\hline Other (urban, rural residential, waste and mining, water and unknown) & 155850 & 2.02 \\
\hline Total & 7687147 & 100.00 \\
\hline
\end{tabular}

Source: Based on ABARE-BRS [13, 14]

Table 1. Summary of land use in Australia

\section{Major impacts on Australian biodiversity}

Schedules to Australia's Environmental Protection and Biodiversity Conservation Act (EPBC) [18] list 1298 species of "Threatened Flora" (of which 39 are recorded as "extinct", 139 as critically endangered, 528 as endangered, and 592 as vulnerable [19], and 451 species of threatened fauna of which 54 are recorded as extinct, 1 as extinct in the wild, 54 as critically endangered, 142 as endangered, 193 as vulnerable and 6 as "conservation dependent" [20]. The EPBC also lists 70 Threatened Ecological Communities as vulnerable, endangered or critically endangered [21]. (Note: this is the current number in the EPBC schedule with the most recent entry dated 17 July 2014. The State of the Forests report [1, p94] states "at December 2012, the EPBC Act listed 58 threatened ecological communities, of which 27 are forest communities or contain significant proportions of forest ". For this chapter, we accept the EPBC schedule).

The EPBC Act recognises 21 specific threatening processes. Clearing and replacement of vegetation, along with the introduction of new animal species (including both herbivores and predators), the spread of invasive plant and animal species, changes in fire regimes, manipulation of the distribution and quantity of water resources in both time and space, and changes to the physical, chemical and biological state of the continent's generally ancient and impoverished soils, have all contributed to rapid and extensive loss of biodiversity, including a high rate of species extinction [2,22]. Widely accepted assessments of the course of climate change point to a further increase in pressures on the biodiversity and ecosystem services of Australian environments [3, 23-25]. 


\subsection{Vegetation clearance}

The most dramatic and widespread impact on ecosystem structure and ecological function has been land clearance - removal and/or conversion of vegetative type and cover. Australia's 2013 State of the Forests report [1] notes that clearing or modification for urban settlements and intensive agriculture has affected as much as one third of native vegetation, with some communities reduced to as little as $1 \%$ of their original areas and others highly fragmented. Resultant landscapes are a diverse mosaic of fragmented and modified native vegetation and converted and replaced land cover [26, 27]. The loss of habitat is reflected in long lists of threatened plant and animal species.

\subsection{Fire in Australian landscapes}

Fire is a major driver, responsible for the composition of a great many Australian ecosystems, including most of its forests [28, 29]. Even before European settlement, many Australian ecosystems were fire-generated and fire-dependant [28]. As settlement extended further inland, fire was widely used as a tool for land clearance.

Fire is an important tool for management and can be used in the service of biodiversity objectives but uncontrolled wildfires and inappropriate fire regimes continue to pose an ongoing threat to maintenance of biodiversity. Problems range from fire regimes that are too infrequent and allow the build-up of excessive fuel loads (often contributing to highly damaging wildfires) to burning regimes that are too frequent to allow regeneration, reestablishment and regrowth of affected communities [30,31]. Suppression and, in many cases, the exclusion of fire has been equally as problematic for ecosystem function as have wildfire or too frequent fire regimes.

Appropriate fire regimes will be increasingly important for management of the expected effects of climate change on fuel loads, temperature, humidity and other drivers. An increase in the frequency, intensity and area affected by fire and a reduction in the period available for safe control burning to manage fuel loads can be expected [1, 24, 25].

\subsection{Climate change}

There is evidence that anthropogenic climate change is already impacting ecosystem processes and biodiversity in Australia [2, 4, 32, 33]. Continuing, and probably accelerating impacts, will require adaptive management to counter increasing risks of pests and diseases, altered fire regimes and other expected variations of temperature and rainfall and extreme events [5, 34, 35].

\subsection{Biogeographic regionalisation based on vegetation}

Australia's landscapes have been classified in large homogeneous and distinctive bioregions based on common climate, geology, landform, soil, native vegetation and species information [36]. Currently, there are 89 geographically distinct bioregions which have been further subdivided and mapped into 419 more localized subregions with greater geomorphological homogeneity - see Australia's Bioregions (IBRA) [37]. 
Large areas of Australia, readily identifiable as distinctive biogeographic regions and subregions, are dominated by two genera - Eucalyptus and Acacia. The first, Eucalyptus, is almost unique to Australia-only seven of the more than 800 species occur (naturally) beyond Australia and only one of these does not occur within it $(38,39]$. Native forest and woodland forests dominated by eucalypts comprise 92 million hectares; $75 \%$ of the native forest area $[1,40]$.

The second widely dominant genus is Acacia. Though the genus is widespread elsewhere, most of the phyllodinous acacias are Australian. As with the characteristic sclerophylly of eucalypts, the phyllodinous adaptation of acacias is recognised as a response to characteristic edaphic and climatic conditions of the Australian land mass complicated by the role of fire and their adaptation to it. Acacias are dominant in almost 10 million hectares $-8 \%$ of the forest area [1].

\section{The condition of native plant communities (i.e. vegetation condition) as an indicator of ecosystem function}

Vegetation has long been used to characterise Australian landscapes. Key roles of vegetation in maintaining ecosystem function in Australia are listed in Table 2. The Vegetation Assets, States and Transitions (VAST) system, as described below, builds on the observation that vegetation is a major driving force in the dynamics of terrestrial ecosystems such that, in Australia, it is often used as a proxy to classify ecosystem type and function.

In the $57 \%$ of Australia's land that has been modified to support agriculture and grazing, there is a mix of intact, disturbed and replaced cover types with identifiable vegetation composition, structure and condition classes [17]. This ' $m i x$ ' largely determines ecosystem function and the ecosystem services that a landscape will support [42]. It also underpins the ability to maintain and enhance, or restore, biodiversity - the 'regenerative capacity' of ecosystems. Accordingly, the VAST system recognises that actions to arrest and/or reverse loss of biodiversity must be based on an understanding of the present condition of vegetation, how that condition was reached and what management changes will be required in order to change the structure, composition and function of the vegetation.

While restoring vegetation structure, species composition and regenerative capacity is an effective step towards improving ecosystem function, it may not always be appropriate to aim for overall recovery of biodiversity. The responses of individual species or species assemblages may change as ecosystem function changes in response to management actions or climate change or other events such as wildfire.

\section{Australia's National Reserve System (NRS)}

Australia's Commonwealth (i.e. national), state and territory governments have jointly agreed on a strategy for establishment and management of a national reserve system - a "network of public, indigenous and private protected areas over land and inland freshwater" [43]. The 
objectives for the system are long-term protection of selected ecosystems and the biological diversity they support. The strategy implies a whole-of-landscape approach in recognition that, faced with climate change, the complete, adequate and representative objectives for biodiversity conservation require a "full range of conservation measures applied to other lands across the landscape" $[43, \mathrm{p} 3]$

The national system of reserves includes areas representative of all 89 bioregions. Some 54 $(61 \%)$ of these have greater than $10 \%$ areal (but not necessarily ecosystem) representation. Others - mainly those extensively cleared for cultivation or improved pastures - have very small proportions of their areas in the reserve system. Representation is lower at the next level of the classification where 44 of the 419 subregions (10.5\%) are unrepresented and only 183 $(43 \%)$ have more than $10 \%$ of their area included in the reserve system.

Currently, the National Reserve System (NRS) covers about 13\% of Australia's land area (approximately 100 million hectares) but it has, essentially, been established from what remains of lands with relatively intact vegetation or areas with special biological, historical and/or recreational values. This is particularly the case in over-cleared landscapes that have been converted to intensive agriculture.

In this chapter, we are primarily (but not exclusively) concerned with lands outside the reserve system - i.e. ecosystems or landscapes that are primarily used for agriculture and/or grazing on improved pastures. These show varying degrees of modification. The course of these changes to their original composition, structure and function and the pathway for recovery of these landscapes - i.e. transformation back towards their original state - can be tracked, quantified and displayed by the VAST system here outlined and demonstrated by two case studies. Because the area outside the NRS is very large, reverse transformation of modified landscapes will significantly complement the biodiversity objectives being maintained in reserves. One of the major issues facing public and private land management agencies is how to assess and report the quantum that these landscapes contribute to the national biodiversity account and how their contribution is changing over time. VAST provides information that is relevant to this need. Further, it adds to the available approaches for monitoring responses to climate change and habitat protection at a landscape scale [34].

\section{Approaches to biodiversity objectives - Aiming for maintenance or recovery}

Two approaches are common - one based on land use and the other on land management.

1. As outlined above, Australia has a significant proportion of its land in a system of reserves that are (meant to be) providing for the maintenance of biodiversity. More land (and ecological communities) are given a level of protection under various forms of agreements and these add to the total area of in which maintenance of biodiversity is being supported by control over threatening processes. The total area under various forms of protective designation or agreement is about $118750 \mathrm{sq} \mathrm{km}$ - close to $15.5 \%$ of Australia's land surface 
(excluding Antarctica) $[1,13,44]$. The caveat is that it has not been possible - and never will be possible - to completely control threatening processes such as fire and introduced weeds and animals. Note: similar approaches are being used with a view to maintenance of marine ecosystems and biodiversity, but we are not concerned with marine area protection here. Privately owned and managed reserves comprise only 1\% of Australia (795 sq km) [45].

2. Outside urban areas and the National Reserve System, the majority of Australia's land is managed by farmers and graziers. Most of this is extensive cropping and pastoralism largely due to impoverished soils and the vagaries of climate - but intensification is increasing. Many landowners are well aware of and sympathetic to biodiversity concerns and a number of individual and community initiatives, supported by government programs, are in operation across rural lands. This approach is the main focus of the VAST approach and this chapter.

This effectively means that, for large areas the role of land managers (and citizen scientists and community groups) is critically important to biodiversity maintenance. At local level, much has been done to control invasive weeds and plant trees and shrubs to control land degradation and provide habitat for native species - especially through movements such as LANDCARE. However, a comprehensive study by the National Land and Water Resources Audit [35] included a sub-regional assessment of constraints to community capacity for adaptive management to integrate biodiversity conservation into natural resource management. It concluded that capacity was severely constrained in 14\% of Australia's 419 sub-regions and significantly constrained in another $33 \%$. It found that conservation is 'well integrated into production systems' in only $1.5 \%$ of subregions [35;p130].

Here we describe the use of a Vegetation Assets, States and Transitions (VAST) concept that is proving an effective way to support adaptive management at site, property and local levels. VAST addresses the need for managers to:

1. obtain information on vegetation condition by assessing the effects that land management practices have had on compositional, structural and functional characteristics; and

2. track and report how these characteristics are responding to adaptive changes in their management practices and, where appropriate, relate these responses to indications of climate change.

\section{The VAST transformation approach to assessing change and trend}

VAST is a standardised nationally consistent system for monitoring, evaluating and reporting the effects of changes in land use and management and assessing their effects on ecosystem function and the delivery of ecosystem services. It uses key functional, structural and composition characteristics of a site and its vegetation - fire regime, soil structure, hydrology, nutrients and biology, over and understorey vegetation structure and over and understorey species composition. These ecological criteria are hierarchically integrated with 22 indicators 
that are linked to diagnostic attributes of vegetation condition [17]. A wide range of spatial, temporal and thematic data and information (e.g. environmental histories, relevant time series aerial photography and remote sensing and site-based monitoring) can be used to populate the indicators. The framework is shown in Table 2.

\begin{tabular}{|c|c|c|}
\hline \multicolumn{2}{|c|}{$\begin{array}{l}\text { Key functional, structural and Key Indicators } \\
\text { composition criteria }\end{array}$} & $\begin{array}{l}\text { VAST diagnostic } \\
\text { components }\end{array}$ \\
\hline \multirow{2}{*}{ Fire regime } & 1. Area /size of fire foot prints & \multirow{12}{*}{ Regenerative capacity } \\
\hline & 2. Interval between fire starts & \\
\hline \multirow{2}{*}{ Soil hydrology } & 3. Plant available water holding capacity & \\
\hline & 4. Ground water dynamics & \\
\hline \multirow[b]{2}{*}{ Soil physical state } & 5. Effective rooting depth of the soil profile & \\
\hline & $\begin{array}{l}\text { 6. Bulk density of the soil through changes to soil structure } \\
\text { or soil removal }\end{array}$ & \\
\hline \multirow{2}{*}{ Soil nutrient state } & $\begin{array}{l}\text { 7. Nutrient stress - rundown (deficiency) relative to } \\
\text { reference soil fertility }\end{array}$ & \\
\hline & $\begin{array}{l}\text { 8. Nutrient stress - excess (toxicity) relative to reference soil } \\
\text { fertility }\end{array}$ & \\
\hline \multirow[t]{2}{*}{ Soil biological state } & $\begin{array}{l}\text { 9. Organisms responsible for maintaining soil porosity and } \\
\text { nutrient recycling }\end{array}$ & \\
\hline & 10. Surface organic matter, soil crusts & \\
\hline \multirow{2}{*}{ Reproductive potential } & 11. Reproductive potential of overstorey structuring species & \\
\hline & 12. Reproductive potential of understorey structuring species & \\
\hline \multirow{4}{*}{ Overstorey structure } & 13. Overstorey top height (mean) of the plant community & \multirow{9}{*}{-Vegetation structure } \\
\hline & 14. Overstorey foliage projective cover (mean) of the plant & \\
\hline & community & \\
\hline & $\begin{array}{l}\text { 15. Overstorey structural diversity (i.e. a diversity of age } \\
\text { classes) of the stand }\end{array}$ & \\
\hline \multirow{5}{*}{ Understorey structure } & 16. Understorey top height (mean) of the plant community & \\
\hline & 17. Understorey ground cover (mean) of the plant & \\
\hline & community & \\
\hline & 18. Understorey structural diversity (i.e. a diversity of age & \\
\hline & classes) of the plant & \\
\hline \multirow{3}{*}{ Overstorey composition } & 19. Densities of overstorey species functional groups & \multirow{6}{*}{-Species Composition } \\
\hline & 22. Richness - the number of indigenous overstorey species & \\
\hline & relative to the number of exotic species & \\
\hline \multirow{3}{*}{ Understorey composition } & 21. Densities of understorey species functional groups & \\
\hline & 22. Richness - the number of indigenous understorey species & \\
\hline & relative to the number of exotic species & \\
\hline
\end{tabular}

Source: Thackway, 2013 [46]

Table 2. VAST ecological criteria, performance indicators and diagnostic components 
For practical purposes, the VAST approach uses information on the condition of individual vegetation sites and patches on the premise that the condition of vegetation can be linked to the structure (height, cover, growth form, strata), regenerative capacity (resilience), and composition (species diversity) of vegetation. These are the three components that are used in VAST as indicators or surrogates to determine the response of the plant community and to derive scores for the diagnostic components used to define change in condition and its trend.

Vegetation condition is described as the difference between observed or measured values for diagnostic attributes or criteria relative to a benchmark or 'reference state'. The identification of reference states is a fundamental underpinning of the VAST concept (for details see reference [47]). In Australia the 'original' natural vegetation is often used as a benchmark because of its assumed relationship to biodiversity. Accordingly, residual patches of native vegetation are generally selected as reference sites. In effect, a reference site is an area that is representative of low impact uses and management of the plant community such that the native vegetation has persisted in a largely unmodified state since first European settlement [47].

VAST uses these plant community reference states and representative sites to enable consistent tracking and reporting of change and trend in key characteristics, performance indicators, and diagnostic components. The observed 'distance' of these diagnostic components from any 'fully natural' benchmark provides relative scores that can be summed to assign condition classes.

Table 3 shows the VAST vegetation condition classes. VAST uses a metric approach to classify and map vegetation 'condition states' that are determined by the effects that land use and/or land management practices have on compositional, structural and functional characteristics of the site. The extent to which these characteristics remain intact or, if changed, have been modified, replaced or altogether removed defines the six VAST vegetation classes.

\begin{tabular}{|c|c|c|c|}
\hline & Veg & tation condition classes & Characteristics of the vegetation \\
\hline & 0 & Naturally bare & $\begin{array}{l}\text { Areas where native vegetation does not naturally persist, and } \\
\text { recently naturally disturbed areas where native vegetation has } \\
\text { been entirely removed (i.e. subject to primary succession). }\end{array}$ \\
\hline & I & Residual & $\begin{array}{l}\text { Native vegetation community structure and composition, with } \\
\text { regenerative capacity intact - no significant perturbation from } \\
\text { land use/land management practices. }\end{array}$ \\
\hline Vegetation & II & Modified & $\begin{array}{l}\text { Native vegetation community structure, composition and } \\
\text { regenerative capacity more or less intact, perturbed by land use/ } \\
\text { land management practices such as intermittent low intensity } \\
\text { grazing. }\end{array}$ \\
\hline & III & Transformed & $\begin{array}{l}\text { Native vegetation partly removed but community structure, } \\
\text { composition and regenerative capacity has been significantly } \\
\text { altered by land use / land management practices. }\end{array}$ \\
\hline & IV & $\begin{array}{l}\text { Largely replaced and } \\
\text { degraded }\end{array}$ & $\begin{array}{l}\text { Native vegetation largely replaced by invasive native and/or } \\
\text { exotic plant species (commonly areas abandoned or burnt). }\end{array}$ \\
\hline
\end{tabular}




\begin{tabular}{lll}
\hline & & $\begin{array}{l}\text { Native vegetation completely removed and replaced with } \\
\text { intensive agriculture: rain-fed broad acre crops, feed lots, }\end{array}$ \\
V & $\begin{array}{l}\text { Replaced and managed for } \\
\text { intensive production }\end{array}$ & $\begin{array}{l}\text { horticulture, irrigation agriculture and long or short rotation } \\
\text { forestry. Various types are recognised in the vegetation } \\
\text { classification. }\end{array}$ \\
\hline \multirow{2}{*}{ VI } & $\begin{array}{l}\text { Replaced with man-made } \\
\text { structures }\end{array}$ & $\begin{array}{l}\text { Settlements and cultural features - e.g. buildings, roads, water } \\
\text { reservoirs; gardens, parks and amenity plantings. }\end{array}$ \\
\hline
\end{tabular}

Table 3. Vegetation characteristics of VAST condition classes

\section{Theoretical underpinning of VAST-a model of temporal change}

A land manager who wants to change a landscape will need to understand how managing the 10 VAST criteria can restore a site (or landscape) towards a reference state. This applies whether specifically to recover some species or improve species diversity in general, or to more broadly improve the production of ecosystem services (e.g. the generation of food and fibre and regulation of the hydrological regime while providing habitats and food sources to support increased biodiversity).

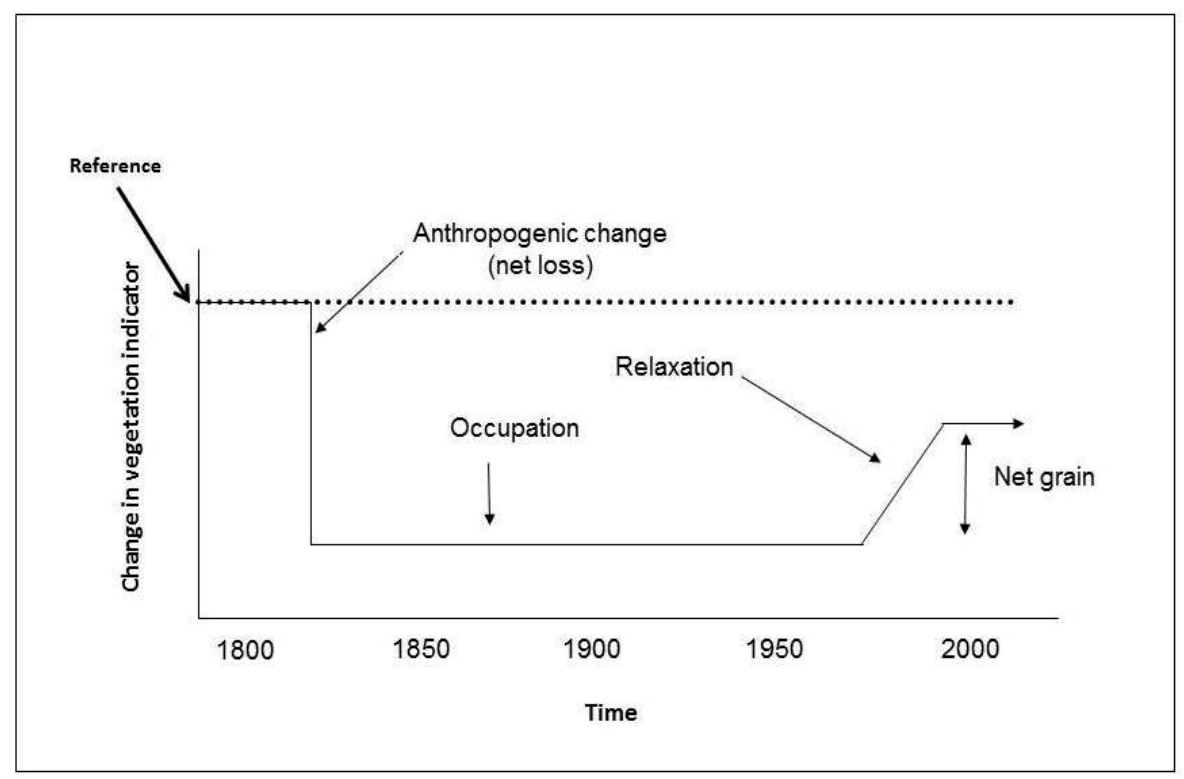

Figure 1. Transformation, occupation and relaxation of a given area of land (based on Hamilton et al. 2008 [48]). 
Figure 1 presents the theory underpinning the VAST approach to understanding temporal changes in vegetation indicators in response to changes in land use and management. While a site is being managed using a suite of land management practices it is 'occupied' and there is a net loss in some (or all) of the key indicators relative to the reference state. Where a land manager chooses to relax previous land management practices, allowing reversion of their effect so that the site can recover or be significantly restored, there is a net gain in indicator(s) relative to the reference state.

\section{A report card on change - Tracking impacts of land use and management}

The VAST system can provide a simple graphical report card showing change and trend relative to a reference state (i.e. natural benchmark). The manager and/or researcher compiles information on how ecosystems within a (selected) landscape have reached their current state (i.e. what happened and what is happening now). This information can be used to model how vegetation - and therefore ecosystems - might be restored within the scope of the objectives of the manager(s) of a landscape. This provides a baseline and rationale for monitoring changes in the vegetation structure, species composition and regenerative capacity of the site following the changes made to land management practices. The results can be used to inform stakeholders of progress towards agreed targets for ecosystem structure and function and/or biodiversity.

One of the most important premises of the VAST system is that, while it emphasises vegetation structure and composition, it essentially operates on and achieves its results through improved understanding and management of the key functional, structural and composition components at a site relative to the reference state. Within the limits imposed by regional climate and microclimates, the recovery of native vegetation communities largely depends on partially or fully reinstating the soil structure, hydrology, nutrients and biology - often the very criteria most affected by land clearance, cultivation and the introduction of hard-hoofed animals. Fire regime and reproductive potential are also critically important criteria particularly in most grassland and woodland ecosystems many of which, along with some forest ecosystems, are managed for pastoral production.

Figure 2 illustrates these concepts using a Poplar Box (Eucalyptus populnea) plant community. At time one ( $\mathrm{t} 1$ ) the site is minimally managed. At $\mathrm{t} 1$ the site is classified as in an unmodified state (VAST class I). At time two (t2), land management practices have been used to change the vegetation structure and composition characteristics, although the functional characteristics of the site are largely unchanged. The condition at $\mathrm{t} 2$ is classified as a modified state (VAST class II). At time three (t3) land management practices are intensified to further change the vegetation structure and composition characteristics, although the functional characteristics of the site still are largely unchanged. The condition at $\mathrm{t} 3$ is classified as a transformed state (VAST class III). Figure 2 shows the direct relationship between the VAST condition classes of the site and the delivery of ecosystems services [41]. 


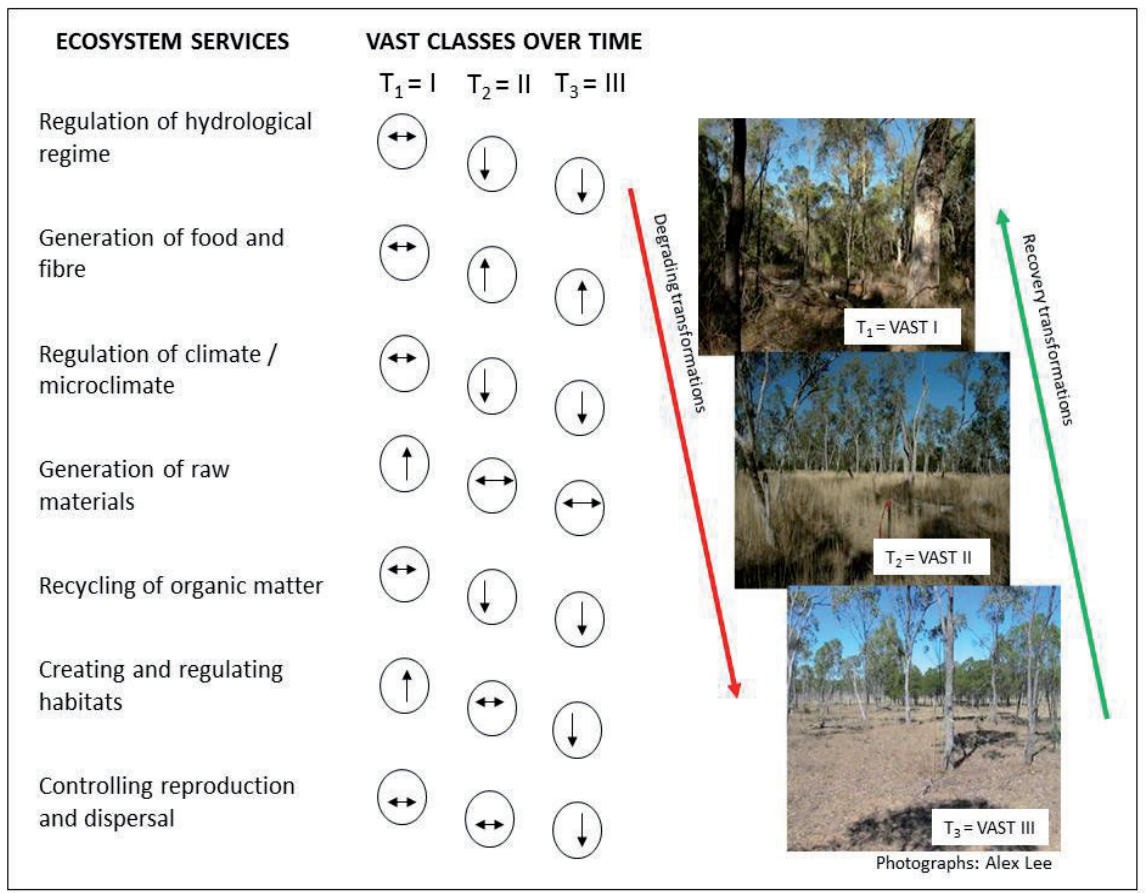

Figure 2. Trajectory of VAST classes and the effect on ecosystem services

\section{Application of VAST to the problem of fragmentation}

Given the importance attached to the integrity and extent of native vegetation, its fragmentation at local and regional scales poses a number of threats to maintenance of biodiversity. Apart from lack of connectivity for passage between refuges and food sources, there is increasing concern about the risk of declining genetic diversity (inbreeding), especially in the context of climate change [1, 24]. In the VAST system, this is largely encapsulated in indicators of reproductive potential and in overstorey and understorey structure and composition (see Table 2).

McIntyre and Hobbs [22] proposed a framework for conceptualizing the effects of landscape fragmentation and increasing degrees of site modification and understanding their relevance to management. The framework is widely known and understood and assists conservation biologists and natural resource managers to address the full spectrum of human impacts observed across agricultural and fragmented landscapes. 
Muetendeudzi and Thackway [49] have adapted this concept to recognise and map 'landscape alteration levels' as an emergent property of vegetation condition at the site level. Figure 3 shows a schematic model characterising landscape alteration levels in terms of the relationship between increasing fragmentation and increasing degrees of modification defined in terms of VAST classes. An appropriate vegetation condition dataset is required for generation of maps of landscape alteration levels. For this, condition classes must be described as homogeneous map units at the site level - i.e. as either mapped polygons or raster based maps [17]. VAST provides a suitable input dataset.

VAST spatial data for fragmentation and degrees of site modification represented are used to classify landscapes into four categories - intact, variegated, fragmented, and relictual - to generate national and regional maps and statistics.. This information can provide a valuable basis for setting conservation priorities in natural management programs [50].

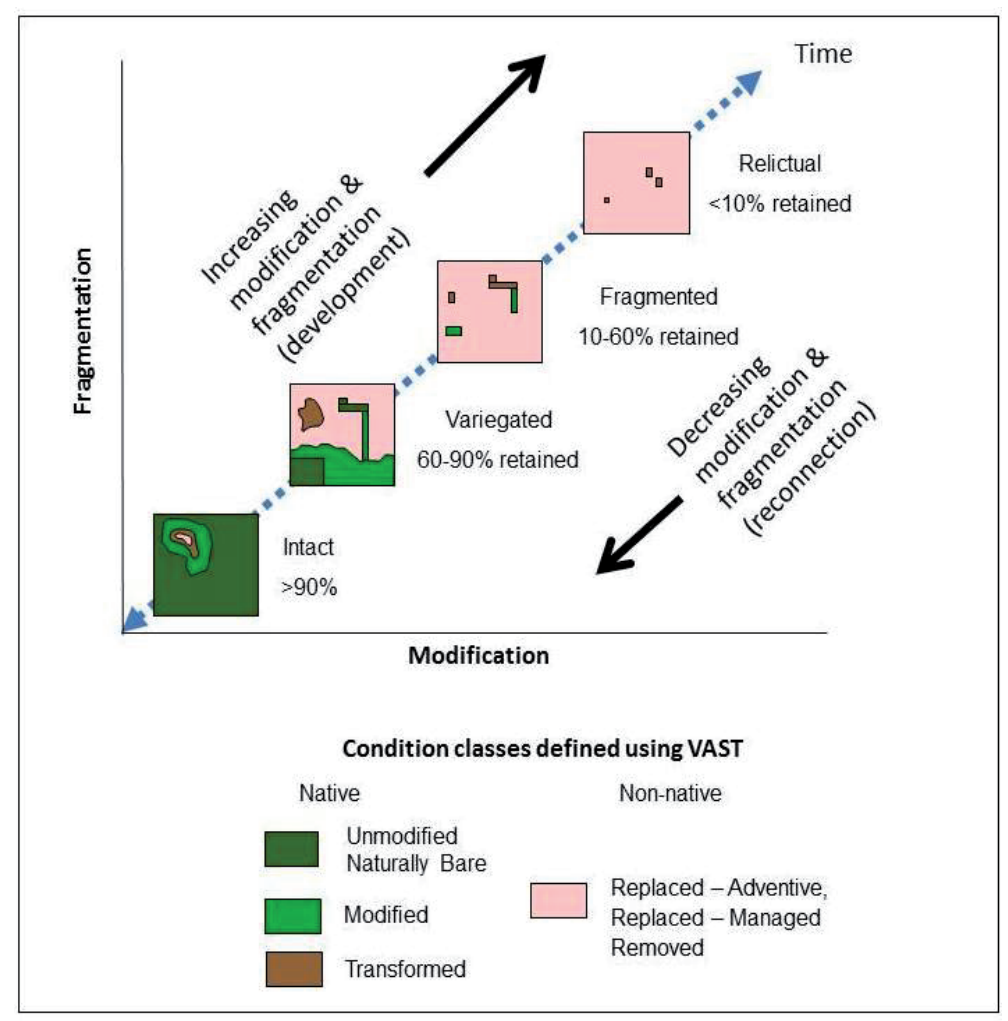

Figure 3. A framework for characterising landscape alteration levels based on increasing fragmentation and increasing degrees of modification defined in terms of VAST classes. 


\section{Application of the VAST approach to site transformation - Two case studies}

Implementation of the approach is shown below in two considerably different case studies one in an area originally sub-tropical rainforest, the other an area of Eucalyptus grassy woodland in a cool temperate climatic environment. The location of the case study sites is shown in Figure 4.

\subsection{Rocky Creek Dam, Big Scrub, New South Wales}

The Rocky Creek Dam, Big Scrub, New South Wales case study is an area of 25 hectares of hilly terrain located $28^{\circ} 38^{\prime} 8.54^{\prime \prime} \mathrm{S}, 153^{\circ} 20^{\prime} 32.58^{\prime \prime} \mathrm{E}$ - see Figure 4 . This 'transformation site' was originally Lowland Subtropical Rainforest on basalt-derived soils (see reference [47] for full definition of 'transformation site'). The site is located in the South Eastern Queensland bioregion and the Scenic Rim sub-bioregion. In 1910 the transformation site was completely cleared of the native rainforest and converted to agriculture. It was cropped in 1910 and then from 1911-49 it was managed as a continuously grazed pasture supporting dairy cattle.

The transformation site is located near a large remnant area of Lowland Subtropical Rainforest. In 1990, the land manager, Rous Water, defined the reference state for the Rocky Creek Dam transformation site as the nearby Rocky Creek Flora Reserve (172 ha), now part of Nightcap Range National Park [51].

The VAST method (criteria and indicators) was used to assess the link between environmental response and land management activity and change over time. Information on land management history and its progressive effects on key ecological criteria and indicators was derived from published and unpublished sources including interviews with the land manager and discussions with ecologists familiar with the site.

Assessment of the indicators was completed as part of field work in 2010 [52].

\subsubsection{Phase 1: $1750-1910$}

This period coincided with cessation of management by the Goori indigenous people, the area was opened-up for selection as private land, the 'cedar getters' selecting, cutting and removing large trees. During this period the area remained as VAST I (unmodified 80-100\%).

\subsubsection{Phase 2: 1911-1949}

Commencing in 1911 the site was transformed from VAST I unmodified 80-100\%, through VAST II modified 60-80\%; to VAST III transformed 40-60\%.

This phase was characterised by the conversion of the rainforest to pasture and its continuing use for dairying. This included pasture improvement and continuous or set stocking. The aim of land management during this period was to maintain and improve milk production by grazing dairy cows on improved exotic pastures. Regeneration of the rainforest was actively controlled. 

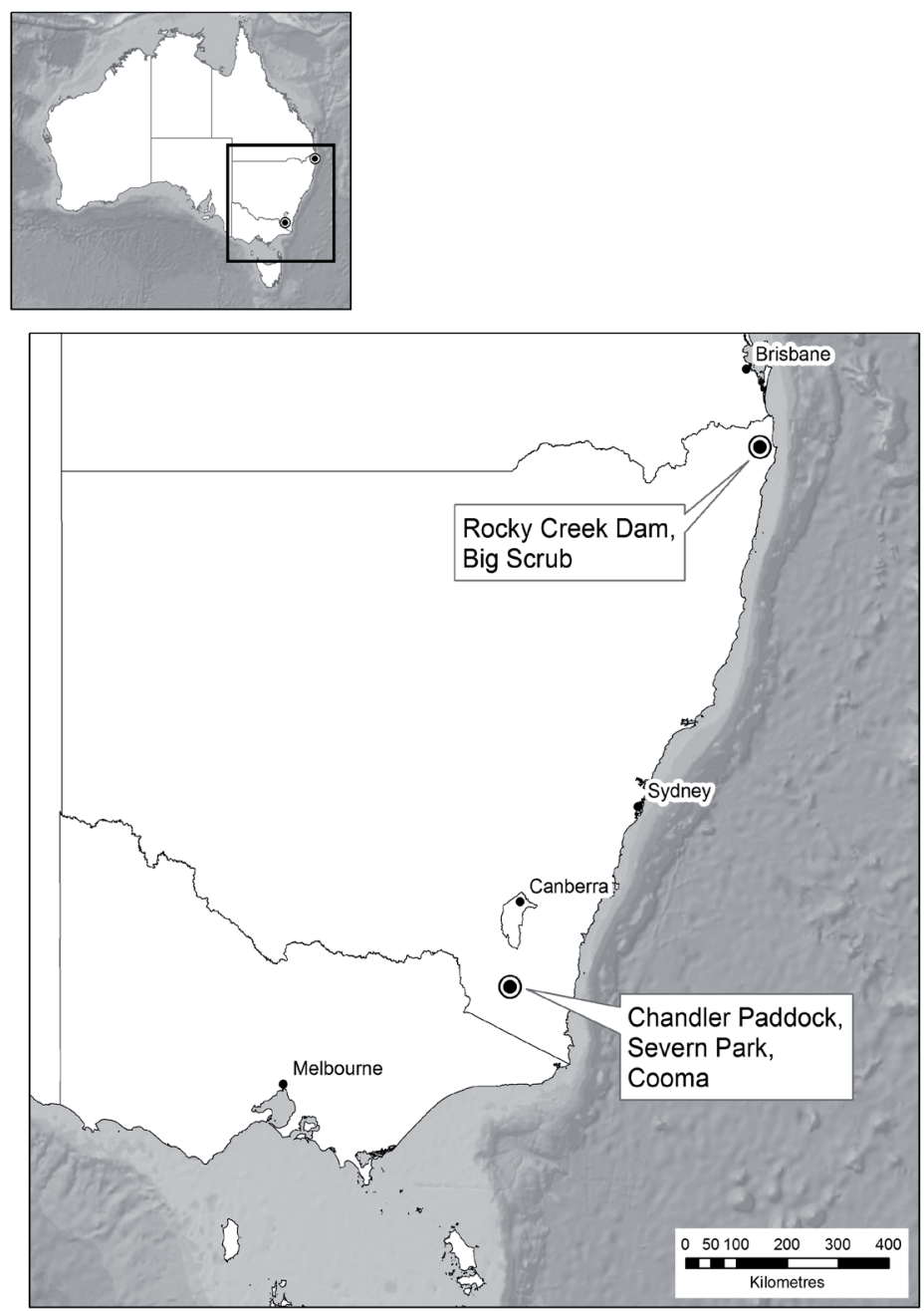

Figure 4. Location of the Case Study areas

During this period the vegetation condition scores were dramatically reduced from $100 \%$ to $43 \%$. Initially, with the conversion of the rainforest vegetation, condition scores were reduced from unmodified (80-100\%) to transformed (56\%) with the major change due to the loss of vegetation structure and species composition. Subsequently ecological function was further diminished due to changes in soil hydrology, soil nutrients, soil biology and reproductive potential of the plant community. At the end of this phase the score was $43 \%$. 


\subsubsection{Phase 3: 1950-1982}

Commencing in 1950 the site was classified as VAST III (transformed 40-60\%).

This period was characterised by the transfer of ownership of the land from private to public. Several private properties, including this site, were purchased by Rous Water as part of the Rocky Creek water catchment area within which the Rocky Creek Dam was to be built. The cessation of dairying and the abandonment of pasture management, resulted in a major incursion of lantana (Lantana montevidensis). The Dam was built in 1950-52.

During this period birds and flying foxes (Pteropus spp.) which had spent time in the adjacent large remnant dropped their faeces into the lantana. The lantana was also ameliorating the soil conditions that had been degraded during the earlier period of dairying.

The land manager commenced experiments on small test plots using assisted regeneration of the rainforest by controlling the regeneration of lantana. This showed that the rainforest could be readily re-established.

At the end of Phase 3 in 1990 the site as a whole was still classified as VAST III (transformed 40-60\%).

\subsubsection{Phase 4: 1983-2010}

This period was characterised by large-scale assisted regeneration which commenced in 1993 and was largely completed in 1999. The process used was to systematically convert small patches covered entirely with lantana, within the site, back towards the original Lowland Subtropical Rainforest composition, structure and condition. The main technique was to slash the lantana to create ground cover mulch and then, as germination of the lantana was observed, use weed killer to halt its re-establishment. The earlier experiments had shown that the rainforest plants geminated later than lantana, thus enabling this system of assisted regeneration to be highly successful.

In 1991 the land manager, Rous Water, commenced detailed monitoring and reporting of the key attributes of species composition and vegetation structure associated with the assisted regeneration.

Since 2001, the site of restored Lowland Subtropical Rainforest, adjacent to the Rocky Creek Dam reservoir, has been managed continuously as open public space.

At the end of Phase 4 in 2010 the site was classified as VAST I (unmodified) with a score of (about) $90 \%$.

Figure 5 shows the change and trend in the transformation of the Rocky Creek Dam transformation site. The symbols depicted in the graph are based on qualitative observations and quantitative measurements $(x 1, x 2, x 3)[53,54]$.

The figure shows total vegetation status score calibrated to VAST classes:

$80-100 \%$ of the reference state corresponds to VAST class I- Residual/Unmodified; 
$60-80 \%$ corresponds to VAST class II- Modified;

40-60\% corresponds to VAST class III- Transformed;

Scores from $0-39 \%$ corresponding to VAST class IV- Replaced and adventive; VAST class V- Replaced and managed; and VAST class VI Replaced and removed have not been differentiated.

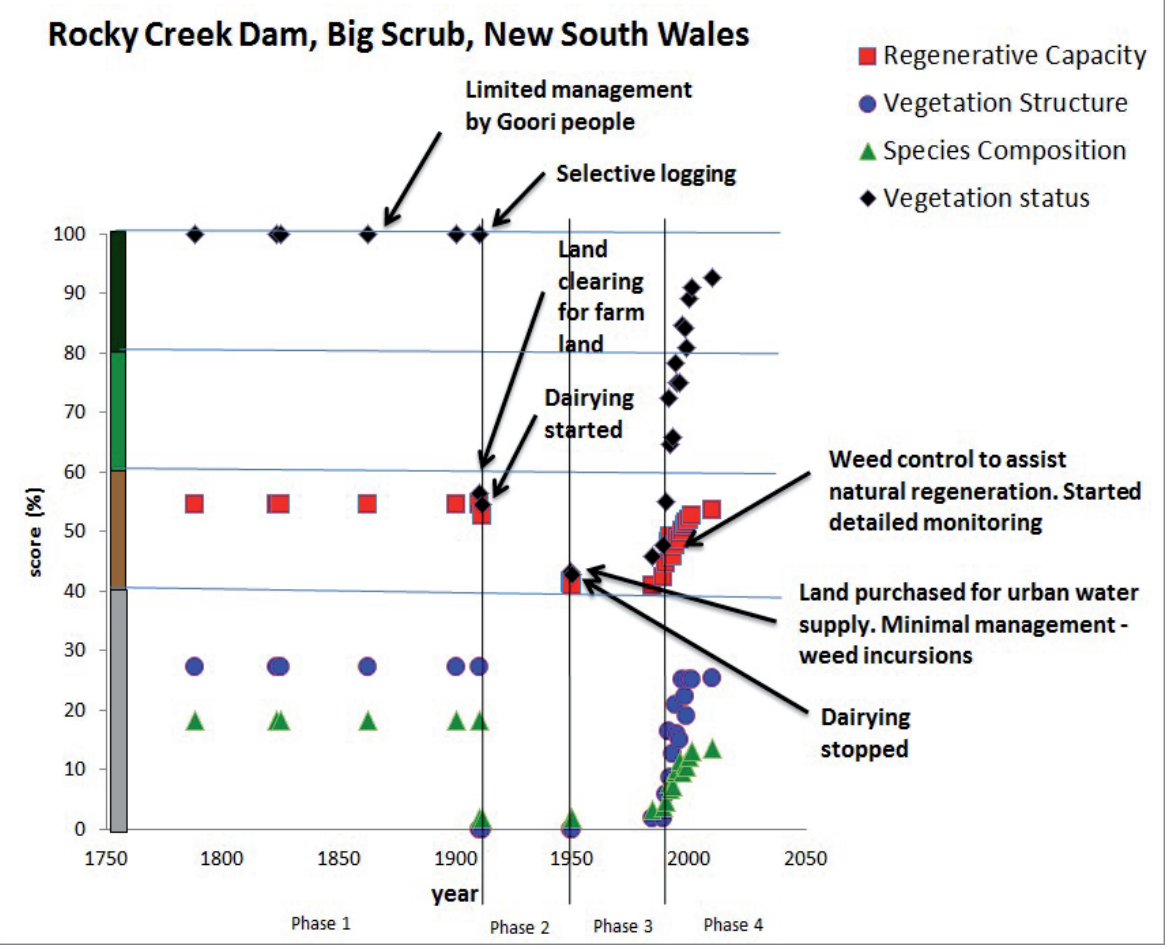

Figure 5. Phases in the transformation of Rocky Creek Dam site.

\subsection{Chandler Paddock, Monaro Region, New South Wales, Case study}

\subsubsection{Introduction}

Chandler paddock, Severn Park, Cooma, New South Wales is an area of 107 hectares comprising rolling and hilly terrain; located-36 $26^{\prime} 23.4600^{\prime \prime} S, 148^{\circ} 55^{\prime} 42.0000^{\prime \prime E}$ - see Figure 4 . The site is located in the South Eastern Highlands bioregion and the Monaro sub-bioregion of the Interim Bioregions of Australia classification [36]. 
This 'transformation site' was originally Eucalyptus pauciflora and E. rubida woodland over scattered shrubs, over a Themeda and Poa grassland with mixed forbs. The soils are derived from granite. In 2013, the land manager, defined the reference state for Chandler paddock transformation site as an extant patch of Eucalyptus pauciflora woodland in Carter paddock, also located on Severn Park (Charles Massy pers comm).

The VAST method (criteria and indicators) was used to assess the link between environmental response and land management activity and change over time. Information on land management history and their effects on key ecological indicators and attributes were derived from published and unpublished sources including interviews with the land manager and discussions with ecologists familiar with the site. Assessment of the VAST indicators was completed as part of fieldwork in 2013.

\subsubsection{History}

Between the 1870s-90s almost all the trees on the upper, mid and lower slopes were ringbarked and killed to promote pasture production. Ridges were not cleared.

\subsubsection{Phase 1: $1750-1855$}

This period coincided with cessation of management by the Ngarigo indigenous people in the mid 1830s. By the end of this period the site was classified as VAST I with a score of $100 \%$.

From 1830, the area was opened-up as grazing land with shepherds continuously moving large flocks of sheep on unfenced natural pastures.

\subsubsection{Phase 2: $1855-1875$}

Grazing on unfenced pastures continued into 1870. Permanent wire fences were erected after 1871 and set or continuous stocking has continued virtually unbroken until July 2014.

Commencing in 1855 almost all trees on the site were killed using technique called ringbarking to promote pasture production. Regeneration of the Eucalyptus trees and understory shrubs was actively controlled. The aim of land management during this period was to improve wool production by grazing merino sheep on native pastures.

By the end of this period the site was classified as VAST I with a score of $95 \%$.

\subsubsection{Phase 3: 1876-1929}

Commencing in 1876 set or continuous grazing was enabled through the erection of wire fences. Over the next 50 years the intensive stocking regime and the naturally relatively low levels of natural productivity resulted in the relatively rapid diminution of key indicators associated with vegetation structure, species composition and ecological function. During this period the site was transformed from VAST I (unmodified $80-100 \%$ ), through VAST II (modified 60-80\%) to VAST III (transformed 40-60\%). 
This period was characterised by high stocking rates and active control of regenerating Eucalyptus trees and understory shrubs. Wildfire was actively excluded. In 1900-02 rabbits also arrived in the district, adding pressure to already overgrazed pastures coinciding with the end of the Federation Drought in 1902. The result was sheet and rill erosion and loss of the top soil, the development of gully erosion and a change in the dominance of pasture grasses from more to less palatable.

By the end of this period the site was classified as VAST III with a score of 50\%.

\subsubsection{Phase 4: 1929-1990}

A new land manager assumed management of the land on its purchase in 1929. A high density of rabbits infestation was brought under control by 1934. In the 1930s, with the declining productivity of the pasture, the land manager gained access to off-site mountain grazing in summer in the nearby Snowy Mountains. Access to off-site grazing rested the pastures and gave relief to the sheep which were stressed from the damaging spear grass (Aristida spp). In 1965 access to summer grazing ceased with the establishment of Kosciuszko National Park. With access to off-site grazing during summer no longer available, the land manager commenced applications of $142 \mathrm{~kg}$ per hectare between 1980 and 2008 to improve the productivity of the pasture. Applications of super-phosphate continued until 2008.

In 1980 an attempt to continue to further increase pasture productivity Chandler paddock was ploughed and sown to a mix of exotic pasture species. By the end of this period the site was classified as VAST IV with a score of $41 \%$.

The previous phases of increased pasture production led the land manager to establish a stud merino flock grazing on improved pastures in 1985.

\subsubsection{Phase 5: 1991-1999}

During this period the land manager observed that the ecosystem had little capacity to recover quickly from drought, had little natural resilience, and that species composition and vegetation structure of the pasture was dependant on high levels of super-phosphate.

Figure 6 shows vegetation structure and species composition scores were the lowest for any of the phases and, by the end of this period the site was classified as VAST IV with a score of $39 \%$.

\subsubsection{Phase 6: 2000-2014}

In 2000 the land manager ceased operating the merino stud and began managing the pasture using principles of in this paddock with flock sheep.

This period is characterised by the cessation of applications of super-phosphate and use of time-based cell grazing to re-establish the native pasture. This was observed to result in a higher number and greater diversity of native grasses and herbs, and increased amounts of ground cover during all seasons of the year, along with higher levels of soil moisture and 
increasing levels of biological activity in the soil. In July 2014 the paddock was sub-divided into 7 sub-paddocks so as to fully implement holistic grazing management.

By the end of this period the site was classified as VAST IV with a score of $47 \%$. The aim of the land manager now is to rehabilitate and to maintain the site within the range of scores $60-80 \%$ i.e. VAST II.

Figure 6 shows the change and trend in the Chandler paddock, Cooma transformation site. The symbols depicted in the graph are based on qualitative observations obtained using expert elicitation by one of the authors interviewing Charles Massey pers comm.

It is important to note that, since the commencement of the assisted regeneration in 1991, there was a small scale treatment to investigate the feasibility of changing the land management objectives to improve the biodiversity objectives.

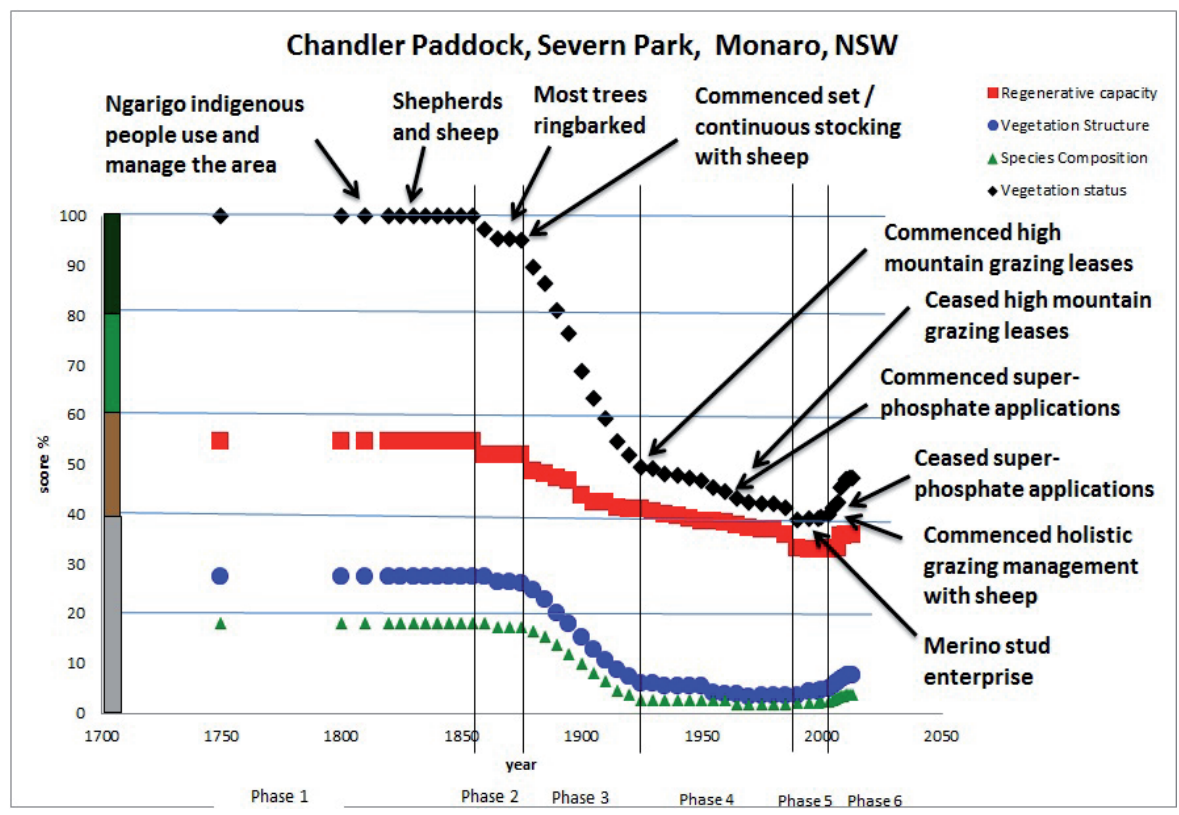

Figure 6. Six phases in the transformation of Chandler paddock, Severn Park, Monaro.

The figure shows total vegetation status score calibrated to VAST classes:

$80-100 \%$ of the reference state corresponds to VAST class I- Residual/Unmodified;

$60-80 \%$ corresponds to VAST class II- Modified;

40-60\% corresponds to VAST class III- Transformed; 
Scores from $0-39 \%$ corresponding to VAST class IV- Replaced and adventive; VAST class V- Replaced and managed; and VAST class VI Replaced and removed have not been differentiated.

\subsection{Summary of the case studies}

Table 2 outlined the ten functional, structural and composition criteria that are the key characteristics for describing condition relative to a 'natural' benchmark. Table 4 shows the relative values for these criteria for three periods - 1910, 1950 and 2010 for the two case study sites. Differences between the values for the two sites in the 2010 records can be partly explained by the interactions between environmental factors - especially wetter sub-tropical vs dryer cool temperate location - and by differences in management objectives. For the Rocky Creek Dam site, the managers objective was full recovery towards the original sub-tropical rainforest with no further incursions of lantana after the exclusion of grazing. For the Chandler Paddock site, the manager's objective was to restore the condition and resilience of a native pasture sufficiently to maintain a sustainable grazing regime with increased productivity.

\begin{tabular}{|c|c|c|c|c|c|c|c|}
\hline & & Ro & ek Dan & & Chanc & dock, $\mathrm{N}$ & Region \\
\hline & Year & 1910 & 1950 & 2010 & 1910 & 1950 & 2010 \\
\hline & Fire regime & $100 \%$ & $100 \%$ & $100 \%$ & $100 \%$ & $100 \%$ & $100 \%$ \\
\hline & Soil hydrology & $100 \%$ & $100 \%$ & $100 \%$ & $70 \%$ & $70 \%$ & $70 \%$ \\
\hline & Soil physical state & $100 \%$ & $95 \%$ & $100 \%$ & $70 \%$ & $70 \%$ & $70 \%$ \\
\hline 를 & Soil nutrient state & $100 \%$ & $70 \%$ & $100 \%$ & $90 \%$ & $90 \%$ & $70 \%$ \\
\hline$\stackrel{\mathscr{Z}}{\omega}$ & Soil biological state & $100 \%$ & $10 \%$ & $100 \%$ & $70 \%$ & $70 \%$ & $70 \%$ \\
\hline 离 & $\begin{array}{c}\text { Reproductive } \\
\text { potential }\end{array}$ & $100 \%$ & $75 \%$ & $90 \%$ & $65 \%$ & $25 \%$ & $15 \%$ \\
\hline$\frac{\pi}{\pi}$ & Overstorey structure & $0 \%$ & $0 \%$ & $87 \%$ & $40 \%$ & $10 \%$ & $0 \%$ \\
\hline$\frac{0}{80}$ & $\begin{array}{c}\text { Understorey } \\
\text { structure }\end{array}$ & $0 \%$ & $0 \%$ & $100 \%$ & $37 \%$ & $30 \%$ & $27 \%$ \\
\hline 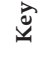 & $\begin{array}{l}\text { Overstorey } \\
\text { composition }\end{array}$ & $10 \%$ & $10 \%$ & $65 \%$ & $40 \%$ & $10 \%$ & $0 \%$ \\
\hline & $\begin{array}{l}\text { Understorey } \\
\text { composition }\end{array}$ & $10 \%$ & $10 \%$ & $85 \%$ & $30 \%$ & $20 \%$ & $20 \%$ \\
\hline & Average scores & $62 \%$ & $47 \%$ & $93 \%$ & $61 \%$ & $50 \%$ & $44 \%$ \\
\hline
\end{tabular}

Table 4. Relative value for VAST criteria for 3 snapshots at the 2 case study sites, benchmarked to the reference state.

A benefit of a standardised national system is that it enables a comparison between the 10 criteria for the two case study sites from two different bioregions (Table 4), however it should be noted that such widely spaced temporal snap shots do not reflect short term improvements in condition which has occurred in several criteria between 1999 and 2010 for the Chandler Paddock, Monaro Region case study site (Figure 6). 


\section{Other applications of the VAST approach}

Australia's vegetation has been classified and mapped into 23 Major Vegetation Groups using information from the National Vegetation Information System [55]. The VAST approach has been applied to assess the condition of these vegetation types and compare the pre-European extent with the current vegetation condition for these groups. Figure 7 shows the 23 groups in seven classes - naturally bare and the six VAST classes ranging from Class I (unchanged) to Class VI (removed).

This information can be used for natural resource planning and program development. For example, it provides an indication of which vegetation types may require additional formal public protection in conservation reserves. The information could also be used to identify those vegetation types where existing VAST class I and class II areas are likely to be further modified by progressive adaptation of land use to the impacts of climate change.

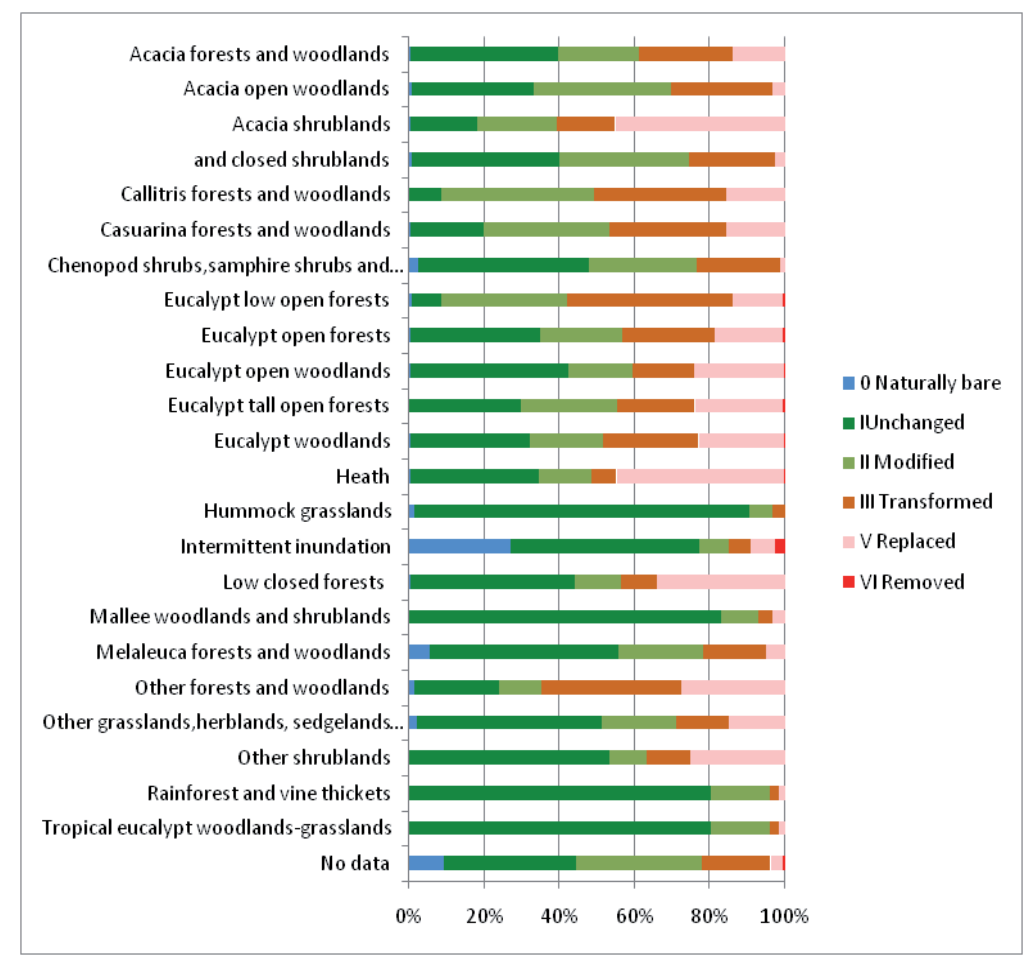

Source ABARES 2011 [55].

Figure 7. Extent of modification of major vegetation groups, as assessed by VAST. Sorted alphabetically 
Information derived for Figure 7 has also been used to assess gross modification between native vegetation (VAST classes 0 , I, II and III) and non-native vegetation (VAST classes V and $\mathrm{VI}$ ) to show the relative areal extent of change from original pre-European vegetation cover to the present extent of Major Vegetation Groups. The summary results are shown in Figure 8.

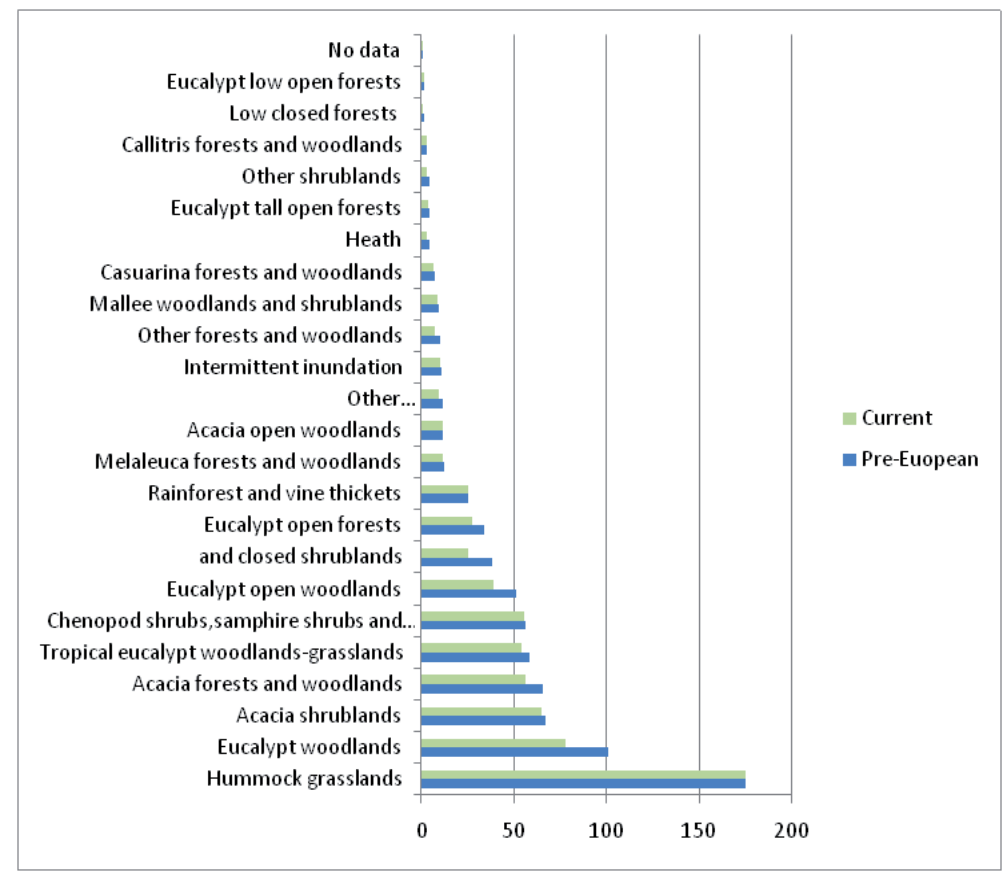

$\overline{\text { Sources: ABARES }}[55]$ and ERIN $[56,57]$.

Figure 8. Current and pre-1750 extent of Australian major vegetation groups. Sorted by area of the major vegetation groups. Area in millions of hectares.

\section{Discussion}

We have described the VAST approach as a tool for managers and researchers to understand the condition of a site or landscape relative to a reference, essentially natural, state. The case studies show how intentional changes in land use and/or land management practices can begin to change condition, sometimes rapidly, on a pathway of reverse transformation. The manager's objectives may be manifold, often economic and aesthetic, but very commonly inclusive of a desire to maintain and enhance biodiversity by improving the quality, extent and/or connectivity of suitable habitat. 
The collection of data for key indicators, their use to inform strategies and targets for change in key functional, structural and composition components, and monitoring of the effect of these strategies is fundamental to the VAST approach. Recording information on the pathway(s) from "original' condition (as defined by a reference state that, as closely as possible, represents pre-European condition) is an essential step if the VAST approach is to be used for reporting progress.

To date, the VAST 2 system has concentrated on changes that have already been made. The next essential step is to record the actions now being taken and to define their intention-i.e. what these actions were intended to achieve and in what time scale it was expected (or hoped) that the changes would have effect. Then it is necessary to have a schedule and defensible method for monitoring how the site and the broader landscape are affected both by the management actions and by external drivers such as weather events and unplanned fire.

We suggest that these essential steps are more broadly applicable to any activity undertaken with the intention to redress degrading impacts in the landscape - e.g. removal and control of invasive weeds. While farmers and other landowners have primary responsibility for such activities on private lands, the work is often done in conjunction with community and other interest groups. In Australia, involvement in 'greening' and a wide range of other environmental activities, is supported by a very large number of groups involving many thousands of often highly committed individuals. While much has been attempted in the design and implementation of government programs to support environmental action - including the development of indicators and guidelines for monitoring and evaluation - there is much more that can be done to achieve wider and more consistent monitoring and reporting, especially of actions undertaken by community groups independently of government programs.

Pilots of VAST have shown that it is possible for management changes to restore a site to conditions that so closely resemble a reference site as to be judged as 'natural'. However, while at times it is possible to achieve such results - usually with a complete change of land use some caution is appropriate with regard to sites for which there continues to be a measurable need for 'production' ecosystem services. Attempting to fully restore original composition is not necessarily always the right approach. Parrotta et al [58] emphasise that "the functional argument for biodiversity conservation does not necessarily depend on reinstating previous ecological conditions, although provisioning, cultural, aesthetic and other benefits or services are often enhanced by native biodiversity".

As noted above, many of Australia's landscapes are now a diverse mosaic of modified native vegetation, 'replaced' vegetation cover types, and fragments of vegetation in 'original' condition. At a landscape scale there is no right or wrong degree of landscape alteration level, i.e. combinations of vegetation modification and fragmentation. However, as public and/or private needs change amid concerns about threats to biodiversity, ecosystem services and economic activity, there is benefit in improving the quality of vegetation condition information that can be used in decision making for natural resource management. Along with this, it is clearly important to have an accounting system that can be used to track progress towards the sustainable use and management of native vegetation across all land use types, with obvious relevance for managing biodiversity. 
The VAST system is a flexible tool for identifying what component(s) might to be manipulated to improve vegetation condition; for demonstrating progress toward the desired vegetation condition; and selecting sites which represent least-cost options for future land use changes to improve biodiversity outcomes.

The VAST approach has now been tested and applied to a wide range of sites and landscapes including sub-tropical wet forests, temperate and semi-arid woodlands, grasslands and arid ecosystems. Aside from the two case studies presented here, other examples include:

- regenerating a sub-tropical eucalypt forest on a sand mined dune;

- regenerating a temperate grassy eucalypt woodland to improve its biodiversity and grazing productivity which had become degraded by long-term continuous grazing with sheep;

- regenerating a protected temperate grassland to improve its biodiversity because the area was degraded by heavy grazing by kangaroos;

- regenerating a eucalypt forest to improve its saw log productivity because the area was degraded by heavy and sustained logging pressure;

- regenerating former tropical rainforest on an abandoned dairy farm recently occupied by a dense stand of weeds;

- restoring a former temperate grassy woodland which was converted to improved pasture; and

- regenerating a temperate rainforest after it was logged once.

We suggest that the approach could now be implemented more broadly at both site and landscape scales. We envisage a program for monitoring and reporting by community--based groups to provide consistent information on the trend in biodiversity maintenance that would be especially important as the widely expected impacts of climate change take effect. The elements would be:

1. agreed standards for collection and recording of data

2. standards for description of the location, size, previous and current use and management etc of sites - based on geocoding standards and LUMIS protocols [13]

3. agreed methods for assessing indicators of structure, composition and function - based on the VAST 2 Handbook [47]

4. standards for defining objectives and targets and monitoring progress - based on Monitoring, Evaluation, Reporting and Improvement (MERI) schedules for cooperative government programs [59].

\section{Conclusion}

The Vegetation Assets, States and Conditions concept provides a reliable approach to identifying the current condition of a site, identifying appropriate actions to transform the site, and 
recording change in response to both these actions and external events. Being a landscape approach, it enables a user to visualise and evaluate the costs and benefits of trade-offs between economic and environmental objectives at a spatial scale at which the delivery of ecosystem services can meaningfully be influenced and reported. The results also provide a rationale for prioritising investment in restoring ecological function and for assisting stakeholders to prepare for, and adapt, to climate change.

Restoring the composition, structure and resilience of vegetation is a viable and effective pathway for improving ecological function and maintaining or recovering biodiversity. We have presented a range of information products that are designed to improve the general understanding of the spatio-temporal processes and patterns and of vegetation condition and how these are affected positively and negatively by land use and the management of native vegetation. These information products highlight the observation that, contrary to much popular opinion, degraded and highly modified ecosystems can be restored and regenerated and that restored ecosystems can again actively contribute to achieving multiple benefit outcomes at site and landscape scales. These benefits include the maintenance and recovery of biodiversity and sustainable use of vegetation.

The case studies show that compiling information and reporting on standardized indicators will give land managers and other decision makers a proper understanding of the nature of change and trend and enable them to consider future states, plan management interventions, and make adjustments in land management programs. Thereafter it is important and, using the VAST format, it is a relatively straightforward task to monitor and report ecological outcomes in the short, medium and long-term.

\title{
Author details
}

\author{
Graham A. Yapp ${ }^{1}$ and Richard Thackway ${ }^{2^{*}}$ \\ *Address all correspondence to: r.thackway@uq.edu.au
}

1 Auricht Projects, Canberra, Australia

2 School of Geography, Planning and Environmental Management, University of Queensland, Australia

\section{References}

[1] Montreal Process Implementation Group for Australia and National Forest Inventory Steering Committee. Australia's State of the Forests Report 2013. Canberra: ABARES; 2013. http://www.daff.gov.au/ABARES/forestsaustralia/Documents/sofr2013web2.pdf (accessed 23 July, 2014). 
[2] State of the Environment Committee. Australia state of the environment 2011. Independent report to the Australian Government Minister for Sustainability, Environment, Water, Population and Communities. Canberra: Australian Government; 2011.

[3] Gammage B. The Biggest Estate on Earth. Sydney:Allen and Unwin; 2011.

[4] Australian Bureau of Statistics. 4613.0-Australia's Environment: Issues and Trends, January 2010. 2 http://www.abs.gov.au/AUSSTATS/abs@.nsf/Lookup/ DD486E7A8C8F95A4CA2576C000194E09?opendocument (accessed 23 July 2014).

[5] Steffen W, Burbidge A, Hughes L, Kitching R, Lindenmayer D, Musgrave W, Stafford Smith M, Werner P. Australia's Biodiversity and Climate Change. A report to the Natural Resource Management Ministerial Council commissioned by the Australian Government. Collingwood, Victoria: CSIRO Publishing; 2009. http:// www.climatechange.gov.au/sites/climatechange/files/documents/04 2013/biodiversity-vulnerability-assessment.pdf (accessed 23 July, 2014).

[6] Vihervaara P, Kumpula T, Ruokolainen A, Tanskanen A, Burkhard B. The use of detailed biotope data for linking biodiversity with ecosystem services in Finland. International Journal of Biodiversity Science, Ecosystem Services and Management 2012;8(1-2): 169-185. http://dx.doi.org/10.1080/21513732.2012.686120 (accessed 21 July 2014).

[7] Hooper DU, Chapin FS, Ewel JJ, Hector A, Inchausti P, Lavorel S, Lawton JH, Lodge DM, Loreau M, Naeem S, Schmid B, Setala H, Symstad AJ, Vandermeer J, Wardle DA. Effects of biodiversity on ecosystem functioning: a consensus of current knowledge. Ecological Monographs 2005;75 3-35.

[8] Balvanera P, Pfisterer AB, Buchmann N, He JS, Nakashizuka T, Raffaelli R, Schmid B. Quantifying the evidence for biodiversity effects on ecosystem functioning and services. Ecology Letters 2006;9 1146-1156. doi: 10.1111/j.1461-0248.2006.00963.x (accessed 23 July 2014).

[9] Guariguata MR, Balvanera P. Tropical forest service flows: improving our understanding of the biophysical dimension of ecosystem services. Forest Ecology and Management 2009;258 1835-1829.

[10] Thackway R, Lesslie R. Reporting vegetation condition using the Vegetation Assets, States and Transitions (VAST) framework. Ecological Management and Restoration 2006;7(S1): $\quad$ S53-S62. $\quad$ http://onlinelibrary.wiley.com/doi/10.1111/j. 1442-8903.2006.00292.x/abstract (accessed 23 July 2014).

[11] Australian Bureau of Statistics. Population Clock. http://www.abs.gov.au/ausstats/ abs@.nsf/Web+Pages/Population+Clock?opendocument (accessed 23 July 2014).

[12] Lesslie R, Mewett J. (2013). Land use and management: the Australian context. Canberra: ABARES research report 13.1; 2013. http://data.daff.gov.au/data/warehouse/ 
9aal/2013/RR13.1lumAc/RR13.1LandUseManageAustContext v1.0.0.pdf (accessed 23 July 2014).

[13] Australian Bureau of Agricultural and Resource Economics and Sciences (ABARES). Land use of Australia, Interim Version5, 2010-2011. Canberra: Australian Government Department of Agriculture; 2014. http://www.daff.gov.au/ABARES/pages/ publications/display.aspx?url=http://143.188.17.20/anrdl/DAFFService/display.php? fid=pb_ilua5g9ablu20140708_11a.xml (accessed 28 July 2014).

[14] Australian Bureau of Agricultural and Resource Economics - Bureau of Rural Sciences (ABARE-BRS). Catchment Scale Land Use Mapping for Australia. http:// www.daff.gov.au/abares/aclump/pages/land-use/catchment-scale-land-use-reports.aspx (accessed 20 July 2014).

[15] Yapp, GA. Land use: status of information for reporting against indicators under the National Natural Resource Management Monitoring and Evaluation Framework. Canberra: Australian Government National Land and Water Resources Audit; 2008.

[16] Lesslie R, Mewett J, Walcott J. Landscapes in transition: tracking land use change in Australia. Australian Government Department of Agriculture, Fisheries and Forestry: Science and Economic Insights Issue 2.2; 2011. http://data.daff.gov.au/data/warehouse/litlud9ab1079/litlud9abl10790111a/SEI2011.2.2LndscpInTrans LR 1.0.0.pdf (accessed 23 July 2014).

[17] Thackway R, Lesslie R. Describing and mapping human-induced vegetation change in the Australian landscape. Environmental Management 2008;42(4) 572-590.

[18] Australian Government Department of the Environment EPBC Act. Listed Key Threatening Processes. http://www.environment.gov.au/cgi-bin/sprat/public/publicgetkeythreats.pl (accessed 23 July 2014).

[19] Australian Government Department of the Environment. EPBC Act List of Threatened Flora. http://www.environment.gov.au/cgi-bin/sprat/public/publicthreatenedlist.pl?wanted=flora (accessed 23 July 2014).

[20] Australian Government Department of the Environment. EPBC Act List of Threatened Fauna. http://www.environment.gov.au/cgi-bin/sprat/public/publicthreatenedlist.pl?wanted=fauna (accessed 23 July 2014).

[21] Australian Government Department of the Environment EPBC Act. List of Threatened Ecological Communities. http://www.environment.gov.au/cgi-bin/sprat/public/ publiclookupcommunities.pl (accessed 21 July 2014).

[22] McIntyre S, Hobbs RJ. (1999) A framework for conceptualising human impacts on landscapes and its relevance to management and research models. Conservation Biology 1999;13(6) 1282-1292. DOI: 10.1046/j.1523-1739.1999.97509.x (accessed 15 June 2014). 
[23] Byrne M, Prober S, McLean E, Steane D, Stock W, Potts B, Vaillancourt R. Adaptation to Climate in Widespread Eucalypt Species. Gold Coast: National Climate Change Adaptation Research Facility; 2013.

[24] Doley D. The response of forests to climate change: the role of silviculture in conserving threatened species. Australian Forestry 2010;73 115-125.

[25] Williams RJ, Bradstock RA, Cary GJ, Enright NJ, Gill AM, Liedloff AC, Lucas C, Whelan RJ, Andersen AN, Bowman DJMS, Clarke PJ, Cook GD, Hennessy KJ, York A. Interactions Between Climate Change, Fire Regimes and Biodiversity in Australia: A Preliminary Assessment. Canberra Australian Government Department of Climate Change and Department of the Environment, Water, Heritage and the Arts; 2009. http://climatechange.gov.au/climate-change/publications/interactions-between-climate-change-fire-regimes-and-biodiversity-australia-preliminary-assessment $\quad$ (accessed 21 July 2014).

[26] Thackway R, Lymburner L, Guerschman JP. Dynamic land cover information: bridging the gap between remote sensing and natural resource management. Ecology and Society 2013;18(1) 2. http://dx.doi.org/10.5751/ES-05229-180102 (accessed 23 July 2014).

[27] Lymburner L, Tan P, Mueller N, Thackway R, Thankappan M, Islam A, Lewis A, Randall L and Senarath U. The National Dynamic Land Cover Dataset. Canberra: Geoscience Australia; 2011.

[28] Gill AM. Fire and the Australian flora: a review. Australian Forestry 1975;38 4-25.

[29] Luke H, McArthur AG. Bushfires in Australia. Canberra: Australian Government Publishing Service; 1978.

[30] Russell-Smith J, Yates CP, Whitehead PJ, Smith, R. Craig R, Allan GE, Thackway R, Frakes I, Cridland S, Meyer MCP, Gill AM. Bushfires 'down under': patterns and implications of contemporary Australian landscape burning. International Journal of Wildland Fire 2007;16(4) 361-377.

[31] Gill, AM. How fires affect biodiversity. In: Fire and Biodiversity: the effects and effectiveness of fire management. Biodiversity Series1996; Paper Number 8. Canberra: Department of Environment, Sport and Territories, 1996. http://www.environment.gov.au/archive/biodiversity/publications/series/paper8/paper4.html (accessed 26 July 2014).

[32] House of Representatives Standing Committee on Climate Change, Environment and the Arts. Managing Australia's biodiversity in a changing climate: the way forward. Final report of the inquiry into Australia's biodiversity in a changing climate. Canberra: The Parliament of the Commonwealth of Australia; 2013. http:// www.aph.gov.au/parliamentary business/committees/house of representatives committees?url=ccea/ccbio/report/finalreport/index.htm (accessed 24 July 2014). 
[33] Reside AE, VanDerWal J, Phillips BL, Shoo LP, Rosauer DF, Anderson BJ, Welbergen JA, Moritz C, Ferrier S, Harwood TD, Williams KJ, Mackey B, Hugh S, Williams YM, Williams SE. Climate change refugia for terrestrial biodiversity: defining areas that promote species persistence and ecosystem resilience in the face of global climate change. Gold Coast: National Climate Change Adaptation Research Facility; 2013. http://www.nccarf.edu.au/publications/climate-change-refugia-terrestrial-biodiversity (accessed 23 July 2014).

[34] Dunlop M, Brown PR. Implications of Climate Change for Australia's National Reserve System-A Preliminary Assessment. Report to the Department of Climate Change, February 2008. Canberra: Department of Climate Change: 2008. http:// www.climatechange.gov.au/sites/climatechange/files/documents/03 2013/nrs-report.pdf (accessed 10 July 2014).

[35] Sattler P, Creighton C. Australian Terrestrial Biodiversity Assessment 2002. Canberra: National Land and Water Resources Audit; 2002.

[36] Thackway R, Creswell ID. An interim biogeographic regionalization for Australia: a framework for setting priorities in the National Reserves System Cooperative Program. Canberra: Australian Nature Conservation Agency; 1995.

[37] Australian Government Department of the Environment. Australia's Bioregions (IBRA). http://www.environment.gov.au/topics/land/national-reserve-system/ science-maps-and-data/australias-bioregions-ibra/australias (accessed 20 July 2014).

[38] Bureau of Flora and Fauna. Flora of Australia: Volume 1 Introduction. Canberra: Australian Government Publishing Service; 1981.

[39] Brooker MIH, Slee AV, Connors JR. Eucalypts of Southern Australia. (EUCLID 2nd Edition about eucalypts) Collingwood, Victoria: CSIRO Publishing; 2002. http:// www.anbg.gov.au/cpbr/cd-keys/Euclid/sample/html/learn.htm (accessed 24 July 2014).

[40] ABARES. Australia's forests at a glance 2012. Canberra: Australian Government Department of Agriculture, Fisheries and Forestry; 2012. http://www.forestlearning.edu.au/sites/default/files/resources/documents/ForestsAtGlance 2012 v1.0.0.pdf (accessed 20 July 2014).

[41] Yapp G, Walker J, Thackway R. Linking vegetation type and condition to ecosystem goods and services. Ecological Complexity 2010;7(3) 292-301.

[42] Folke C, Carpenter S, Walker B, Scheffer M, Elmqvist T, Gunderson L, Holling CS. Regime shifts, resilience, and biodiversity in ecosystem management. Annual Revue of Ecology, Evolution and Systematics 2004;35 557-581.

[43] National Reserve System Task Group. Australia's Strategy for the National Reserve System 2009-2030. Canberra: Australian Government; 2009. http://www.environ- 
ment.gov.au/system/files/pages/643fb071-77c0-49e4-ab2f-220733beb30d/files/ nrsstrat.pdf (accessed 24 July 2014).

[44] Australian Government Department of Environment. Collaborative Australian Protected Area Database-CAPAD 2012. http://www.environment.gov.au/node/34737 (accessed 24 July 2014).

[45] Australian Government Department of the Environment. Ownership of protected areas. http://www.environment.gov.au/topics/land/nrs/about-nrs/ownership (accessed 20 July 2014).

[46] Thackway R. Applying a system for tracking the changes in vegetation condition to Australia's forests. In: Brown AG, Wells KF, Parsons M, Kerruish CM. (eds.) Managing our Forests into the 21st Century: proceedings of National Conference, Institute of Foresters of Australia, 4-7 April 2013, Canberra, Australia, p79-91. http://forestryconference.org.au/program/program-abstracts/ifa-2013-conf-papers-thackway (accessed 31 July 2014).

[47] Thackway R. VAST-2: Tracking the Transformation of Vegetated Landscapes. Handbook for recording site-based effects of land use and land management on the condition of native plant communities - Version 3. Brisbane: The University of Queensland, Australian Centre for Ecological Analysis and Synthesis, Terrestrial Ecosystem Research Network 2014. http://aceas.org.au/VAST-2_Manual_v3.0.pdf (accessed 28 July 2014).

[48] Hamilton M, Brown M, Nolan, G. Comparing the biodiversity impacts of timber and other building materials. Report prepared for Forests and Wood Products Australia, Project No. PR07.1050 p50. Melbourne: Forests and Wood Products Australia; 2008. http://www.fwpa.com.au/images/resources/PR07_1050_WEB_Report.pdf (accessed 25 July 2014).

[49] Mutendeudzi M, Thackway R. A method for deriving maps of landscape alteration levels from vegetation condition state datasets. Canberra: Bureau of Rural Sciences; 2010. http://data.daff.gov.au/brs/data/warehouse/pe brs90000004186/lalMethTechRpt 20091208 ap14.pdf (accessed 23 July 2014).

[50] Thackway R. Towards a framework for describing and mapping vegetation condition: observations from temperate woodlands. In: Lindenmayer D, Hobbs R, Bennett A. (eds.) Woodland Conservation and Management. Melbourne: CSIRO Publishing; 2010. p261-270.

[51] Woodford R. Converting a dairy farm back to a rainforest water catchment: the Rocky Creek Dam story. Ecological Management and Restoration 2000:1(2) 83-92.

[52] Sanger JC, Kanowski J, Catterall CP, Woodford R. Ecological Management \& Restoration 2008:9(2); 143-145.

[53] Sanger JC, Kanowski J, Catterall CP, Woodford R. (unpublished field survey data) 
[54] Thackway R. Transformation of Australia's vegetated Landscapes, Big Scrub Rocky Creek Dam, NSW. Brisbane: Australian Centre for Ecological Analysis and Synthesis, University of Queensland; 2012. http://dx.doi.org/10.4227/05/5088F3D486414 (accessed 26 July 2014).

[55] ABARES. Assessing the modification of Australia's native vegetation. Canberra: Australian Government Department of Agriculture 2011. http://data.daff.gov.au/VAST/ (accessed 31 July 2014).

[56] Australian Government Department of the Environment. National Vegetation Information System (NVIS). http://www.environment.gov.au/topics/science-and-research/ databases-and-maps/national-vegetation-information-system (accessed 30 July 2014).

[57] ERIN. Australia-Estimated Pre1750 Major Vegetation Groups-NVIS Version 4.1. http://www.environment.gov.au/metadataexplorer/full_metadata.jsp?docId= \%7BFC5643D0-E060-4CCC-B67F-59CBE7E14BE5\%7D\&loggedIn=false (accessed 31 July 2014).

[58] Parrotta JA, Wildburger C, Mansourian S. eds. Understanding Relationships between Biodiversity, Carbon, Forests and People: the Key to Achieving REDD+Objectives. A Global Assessment Report. Prepared by the Global Forest Expert Panel on Biodiversity, Forest Management, and REDD+. Vienna: IUFRO World Series Volume 31; 2012.

[59] Department of Agriculture and Department of Environment. Monitoring, Evaluation, Reporting and Improvement (MERI). Canberra: Australian Government; 2014. http://www.nrm.gov.au/funding/meri/ (accessed 15 July 2014). 